\title{
Penggunaan Metode Team Product untuk Meningkatkan Ketrampilan dan Prestasi Belajar Seni Budaya tentang Menyusun Ulasan Tertulis Keunikan Gagasan Teknik Pembuatan Fungsi dan Makna Karya Seni Rupa Siswa
}

\author{
Agus Supriyanto \\ SMP N 1 Nusuwungu, Cilacap \\ Rawabangus, Danasri, Nusawungu, Rawabangus, Danasri, Nusawungu, \\ Kabupaten Cilacap, Jawa Tengah \\ Email: bdmartono7@gmail.com
}

\begin{abstract}
Abstrak
Penelitian tindakan kelas ini bertujuan untuk mengetahui dan membuktikan bahwa Metode Team Product dapat meningkatan ketrampilan dan prestasi siswa kelas VIII SMP Negeri 1 Nusawungu Semester I Tahun pelajaran 2015/2016 pada kegiatan pembelajaran Seni Budaya dengan materi menampilkan sikap apresiatif terhadap keunikan gagasan dan teknik karya seni rupa terapan nusantara. Penelitian tindakan sekolah ini terdiri dari 2 siklus yang pelaksanaannya pada tahun 2015 dan pelaksanaannya selam 6 bulan. Dalam penelitian tindakan sekolah ini subyek penelitiannya adalah siswa kelas VIII D SMP Negeri 1 Nusawungu Semester I Tahun Pelajaran 2015/2016 dengan jumlah 32 siswa. Tindakan yang dilakukan pada siklus 1 dan 2 adalah penggunaan metode Team Product pada pembelajaran Seni Budaya dengan materi menampilkan sikap apresiatif terhadap keunikan gagasan dan teknik karya seni rupa terapan nusantara, dengan lembar observasi untuk ketrampilan dan soal ulangan sebagai instrumen. Analisis data menggunakan deskriptif komparatif. Berdasarkan teoritik hipotesis dan empirik menyebutkan melalui penggunaan metode Team Product pada pembelajaran Seni Budaya dengan materi menampilkan sikap apresiatif terhadap keunikan gagasan dan teknik karya seni rupa terapan nusantara terjadi peningkatan ketrampilan dan prestasi belajar siswa kelas VIII D SMP Negeri 1 Nusawungu Semester I Tahun Pelajaran 2015/2016 yaitu dari rata-rata nilai kondisi awal hanya mencapai 64,78 setelah dilakukan tindakan dengan menggunakan metode Team Product pada siklus I nilai rata-rata naik menjadi 79,98 atau terjadi peningkatan 23,5\%. Sedangkan pada siklus 2 nilai rata-rata kelas naik lagi menjadi 84,19 atau naik 5,3\% dari siklus 1 dan 30\% dari kondisi awal. Maka baik secara teoritik maupun empirik melalui penggunaan metode Team Product pada pembelajaran Seni Budaya dengan materi menampilkan sikap apresiatif terhadap keunikan gagasan dan teknik karya seni rupa terapan nusantaradapat meningkatkan ketrampilan dan prestasi belajar dari kondisi awal yang rendah ke kondisi akhir yang tinggi.
\end{abstract}

Kata Kunci : keterampilan, prestasi belajar, dan metode Team Product

\begin{abstract}
This class action research aims to find out and prove that the Team Product Method can improve the skills and achievements of students of class VIII of SMP Negeri 1 Nusawungu Semester I for the academic year 2015/2016 in learning activities in Art and Culture with material showing appreciative attitudes towards the unique ideas and techniques of art works applied archipelago. This school action research consisted of 2 cycles which were implemented in 2015 and carried out for 6 months. In this school action research the research subjects were students of class VIII D of State Junior High School 1 Nusawungu Semester I of the 2015/2016 Academic Year with a total of 32 students.
\end{abstract}


Actions taken in cycles 1 and 2 are the use of the Team Product method in learning Culture and Art with material displaying an appreciative attitude towards the unique ideas and techniques of applied works of the archipelago, with observation sheets for skills and test questions as instruments. Data analysis uses comparative descriptive. Based on theoretical hypotheses and empirical mentions through the use of the Product Team method in learning Cultural Arts with material displaying an appreciative attitude towards the uniqueness of ideas and techniques of applied works of the archipelago there is an increase in the skills and learning achievement of students in class VIII D of State Junior High School 1 Nusawungu Semester I Academic Year 2015 / 2016 ie from the average initial condition value only reached 64.78 after taking action using the Team Product method in the first cycle the average value rose to 79.98 or an increase of $23.5 \%$. Whereas in cycle 2 the grade average value increased again to 84.19 or up $5.3 \%$ from cycle 1 and $30 \%$ from the initial conditions. So both theoretically and empirically through the use of the Product Team method in learning Culture and Art with material displaying an appreciative attitude towards the unique ideas and techniques of archipelago applied art can improve learning skills and achievement from low start conditions to high end conditions.

Keywords: skills, learning achievement, and Team Product methods

\section{PENDAHULUAN}

Pendidikan seni merupakan sarana untuk pengembangan ketrampilan anak. Pelaksanaan pendidikan seni dapat dilakukan melalui kegiatan permainan. Tujuan pendidikan seni dapat dilakukan melalui kegiatan permainan. Tujuan pendidikan seni bukan untuk membina anak-anak menjadi seniman, melainkan untuk mendidik anak menjadi kreatif. Seni merupakan aktifitas permainan, melalui permainan kita dapat mendidik anak dan membina ketrampilan nya sedini mungkin. Dengan demikian dapat dikatakan seni dapat digunakan sebagai alat pendidikan. Pendidikan Seni Rupa adalah mengembangkan keterampilan menggambar, menanamkan kesadaran budaya lokal, mengembangkan kemampuan apreasiasi seni rupa, menyediakan kesempatan mengaktualisasikan diri, mengembangkan penguasaan disiplin ilmu Seni Rupa, dan mempromosikan gagasan multikultural. Saat ini, pelajaran seni budaya kurang mendapat prioritas, karena tidak diujikan secara nasional dan tidak enentukan kelulusan siswa, akibatnya pelajaran seni budaya dianggap hanya pelajaran sampingan yang kurang mendapat prioritas dalam setiap kegiatan pembelajaran siswa. Kondisi ini ternyata sangat mempengaruhi siswa, yaitu dengan munculnya rasa bahwa pelajaran seni budaya bukan suatu pelajaran yang penting di sekolah. Terlepas dari permasalahan tersebut, pelajaran seni budaya sebenarnya akan membantu siswa untuk mengolah dan mengembangkan kemampuan cipta, rasa dan karsa anak. Cara pandang siswa terhadap pelajaran seni budaya ternyata berimbas pada ketrampilan dan prestasi belajarnya yaitu rendahnya ketrampilan dan prestasi belajar siswa pada pelajaran Seni Budaya hampir pada semua kompetensi 
dasar. Berdasarkan dokumen nilai ulangan harian siswa, hanya ada beberapa siswa yang mendapatkan nilai baik, sedangakan siswa yang lain mendapatkan nilai sedang dan kurang. Hal ini ada kemungkinan disebabkan oleh fakor bakat dan minat siswa tetapi bisa juga oleh faktor guru, bakat anak tentu tidak dapat dirubah, akan tetapi sebenarnya dapat diasah apabila guru lebih kreatif dan inovatif dalam setiap pembelajaran Seni Budaya. Rendahnya prestasi belajar siswa di Kelas VIII D juga terlihat pada hasil nilai ulangan harian pelajaran Seni Budaya pada standar kompetensi 1. Mengapresiasi karya seni rupa dengan kompetensi dasar 1.2. Menampilkan sikap apresiatif terhadap keunikan gagasan dan teknik karya seni rupa terapan nusantara dengan KKM KD 78. Dari 32 siswa hanya ada 7 siswa yang mendapatkan nilai di atas KKM KD, sedangkan 25 siswa mendapat nilai di bawah KKM KD. Pasti ada masalah yang menyebabkan rendahnya prestasi belajar siswa, oleh karena itu perlu diambil tindakan khusus untuk mengatasi permasalah ini yaitu dengan memperbaiki pembelajaran pada kegiatan pembelajaran Seni Budaya. Pembelajaran Seni Budaya tentang membuat ulasan tertulis tentang keunikan gagasan, teknik pembuatan, fungsi dan makna karya seni rupa terapan nusantara dengan menggunakan metode Team Product dianggap tepat digunakan oleh guru untuk meningkatkatkan ketrampilan siswa serta dapat membantu siswa memahami konsep-konsep pelajaran sehingga prestasi belajar akan meningkat.

Berdasarkan dokumen nilai ulangan harian siswa, hanya ada 10 siswa yang mendapatkan nilai baik, sedangakan siswa yang lain mendapatkan nilai sedang dan kurang. Selanjutnya, rendahnya prestasi belajar siswa Kelas VIII D di SMP Negeri 1 Nusawungu juga terlihat pada hasil nilai ulangan harian pelajaran Seni Budaya tentang membuat ulasan tertulis tentang keunikan gagasan, teknik pembuatan, fungsi dan makna karya seni rupa terapan nusantara yaitu dari 32 siswa hanya ada 7 siswa yang mendapatkan nilai di atas KKM KD, sedangkan 25 siswa mendapat nilai bibawah KKM KD. Kondisi ini terjadi karena ada suatu permasalahan, oleh karena itu perlu diambil tindakan khusus untuk mengatasi permasalahan ini yaitu dengan memperbaiki pembelajaran pada pelajaran Seni Budaya. Sehingga masalah yang terjadi pada kegiatan pembelajaran siswa Kelas VIII D SMP Negeri 1 Nusawungu seperti terlihat dari rendahnya prestasi belajar pada pelajaran Seni Budaya tentang tentang membuat ulasan tertulis tentang keunikan gagasan, teknik pembuatan, fungsi dan makna karya seni rupa terapan nusantara perlu diatasi dengan mengambil tindakan yang tepat. Pembelajaran Seni Budaya dengan menggunakan metode Team Product dianggap tepat untuk digunakan oleh guru agar dapat membantu $\underline{\text { siswa memahami konsep-konsep Seni Budaya tentang membuat ulasan tertulis tentang }}$ 
keunikan gagasan, teknik pembuatan, fungsi dan makna karya seni rupa terapan nusantara dengan mudah dan cepat, sehingga permasalahan seperti diungkapkan di atas tidak muncul lagi. Setelah dilakukan analisis maka dapat diidentifikaasi akar penyebab rendahnya prestasi belajar Seni Budaya tentang membuat ulasan tertulis tentang keunikan gagasan, teknik pembuatan, fungsi dan makna karya seni rupa terapan nusantara siswa Kelas VIIID SMPN 1 Nusawungu. Berdasarkan identifikasi masalah tersebut di atas, maka perlu dibuat skala prioritas. Masalah-masalah yang sangat mendesak untuk diberi tindakan dalam pembelajaran agar terjadi peningkatan yaitu ketrampilan dan prestasi belajar mata pelajaran Seni Budaya tentang membuat ulasan tertulis tentang keunikan gagasan, teknik pembuatan, fungsi dan makna karya seni rupa terapan nusantara pada siswa Kelas VIII D SMP Negeri 1 Nusawungu Semester I Tahun Pelajaran 2015/2016 yang rendah. Selanjutnya di bawah ini akan diapaprkan kajian teori tentang penelitian.

\section{Keterampilan Belajar Seni Budaya}

Ketrampilan belajar Seni Budaya adalah kemampuan seseorang terhadap suatu hal yang meliputi semua tugas-tugas kecakapan, sikap, nilai dan kemengertian yang semuanya dipertimbangkan sebagai suatu yang penting untuk menunjang keberhasilannya didalam penyelesaian tugas dalam pembelajaran Seni Budaya. Ketrampilan dalam kegiatan belajar mengajar merupakan bentuk kemampuan siswa dalam proses pembelajaran Seni Budaya .

\section{Prestasi Belajar Seni Budaya}

Yang dimaksud dengan prestasi belajar Seni Budaya adalah prestasi belajar yang dicapai peserta didik dalam mata pelajaran Seni Budaya setelah mengikuti kegiatan perbaikan pembelajaran dalam kurun waktu tertentu dan program tertentu. Kurun waktu yang digunakan dalam penelitian tindakan kelas ini adalah tiga minggu sesuai jumlah siklus yang dilaksanakan. Tindakan-tindakan siklus dilaksanakan pada semester II tahun pelajaran 2014/2015. Sebagai bukti telah dikuasainya kemampuan baru itu dinyatakan dengan angka-angka (nilai). Penilaian dilaksanakan melalui teknik tes (tertulis, lisan dan perbuatan). Jadi dalam penulisan laporan perbaikan pembelajaran melelui penelitian tindakan kelas ini yang dimaksud dengan nilai mata pelajaran Seni Budaya adalah nilai yang diperoleh dalam siklus-siklus yang dilaksanakan.

\section{Metode Team Product}

Metode Team Product merupakan metode informal pembelajaran kooperatif. Menurut Huda (2013: 130), dinamakan Team Product karena setiap kelompok diminta untuk berkreasi atau menciptakan sesuatu. Dalam metode Team Product semua hal atau 
kegiatan yang dilakukan oleh setiap kelompok haruslah berbentuk sebuah produk, baik itu abstrak maupun konkret. Untuk memastikan adanya tanggung jawab pada setiap siswa atau individu, guru dapat memberikan peran atau tugas yang berbeda-beda pada masing-masing anggota dalam setiap kelompok untuk menciptakan satu produk kelompok. Pada penerapan metode Team Product ketrampilan siswa akan terbentuk karena metode team product menekankan pada proses belajar yang bersifat kerja sama, sehingga siswa dapat berinteraksi. Selain itu, dalam metode Team Product siswa diminta untuk menciptakan sebuah produk yang kemudian dipresentasikan. Siswa akan mudah mengemukakan gagasannya karena produk tersebut diciptakan sendiri.

\section{METODE PENELITIAN}

Penelitian ini adalah penelitian tindakan kelas (PTK) yang bertujuan untuk Penelitian Tindakan Kelas tentang upaya peningkatan ketrampilan dan prestasi belajar siswa kelas VIII D SMP Negeri 1 Nusawungu Semester I Tahun Pelajaran 2015/2016 pada kegiatan pembelajaran Seni Budaya dengan kompetensi dasar menampilkan sikap apresiatif terhadap keunikan gagasan dan teknik karya seni rupa terapan nusantara melalui penggunaan metode Team Product dimulai pada bulan Juli sampai dengan bulan Juni. Penelitian tindakan kelas penggunaan metode Team Product untuk meningkatkan kreatifitas dan prestasi belajar siswa kelas VIII D SMP Negeri 1 Nusawungu Semester I Tahun Pelajaran 2015/2016 pada kegiatan pembelajaran Seni Budaya dengan kompetensi dasar menampilkan sikap apresiatif terhadap keunikan gagasan dan teknik karya seni rupa terapan nusantara dilakukan kepada siswa SMP Negeri 1 Nusawungu. SMP Negeri 1 Nusawungu terdiri dari 21 rombongan belajar, tetapi tidak semua kelas kami jadikan subjek penelitian. Peneliti hanya melakukan penelitian di kelas VIII D, karena pada tahun pelajaran 2015-2016 peneliti bertugas mengajar di kelas VIII D sesuai dengan SK KBM yang telah diterbitkan kepala sekolah. Dalam penelitian tindakan kelas ini adalah subyek penelitiannya adalah siswa kelas VIII D SMP Negeri 1 Nusawungu Semester I Tahun Pelajaran 2015/2016. Jumlah siswa kelas VIII D SMP Negeri 1 Nusawungu tahun ini berjumlah 32 yang terdiri dari 13 siswa laki-laki dan 19 siswa perempuan.

Tindakan yang dilakukan pada siklus I adalah penggunaan metode Team Product dalam pembelajaran Seni Budaya dengan kompetensi dasar menampilkan sikap apresiatif terhadap keunikan gagasan dan teknik karya seni rupa terapan nusantara dilakukan dalam kelompok besar dan tindakan pada siklus II penggunaan metode Team Product dalam $\underline{\text { pembelajaran Seni Budaya dengan kompetensi dasar menampilkan sikap apresiatif }}$ 
terhadap keunikan gagasan dan teknik karya seni rupa terapan nusantara dilakukan dalam kelompok kecil. Secara lebih rinci dapat dilihat pada gambar berikut:

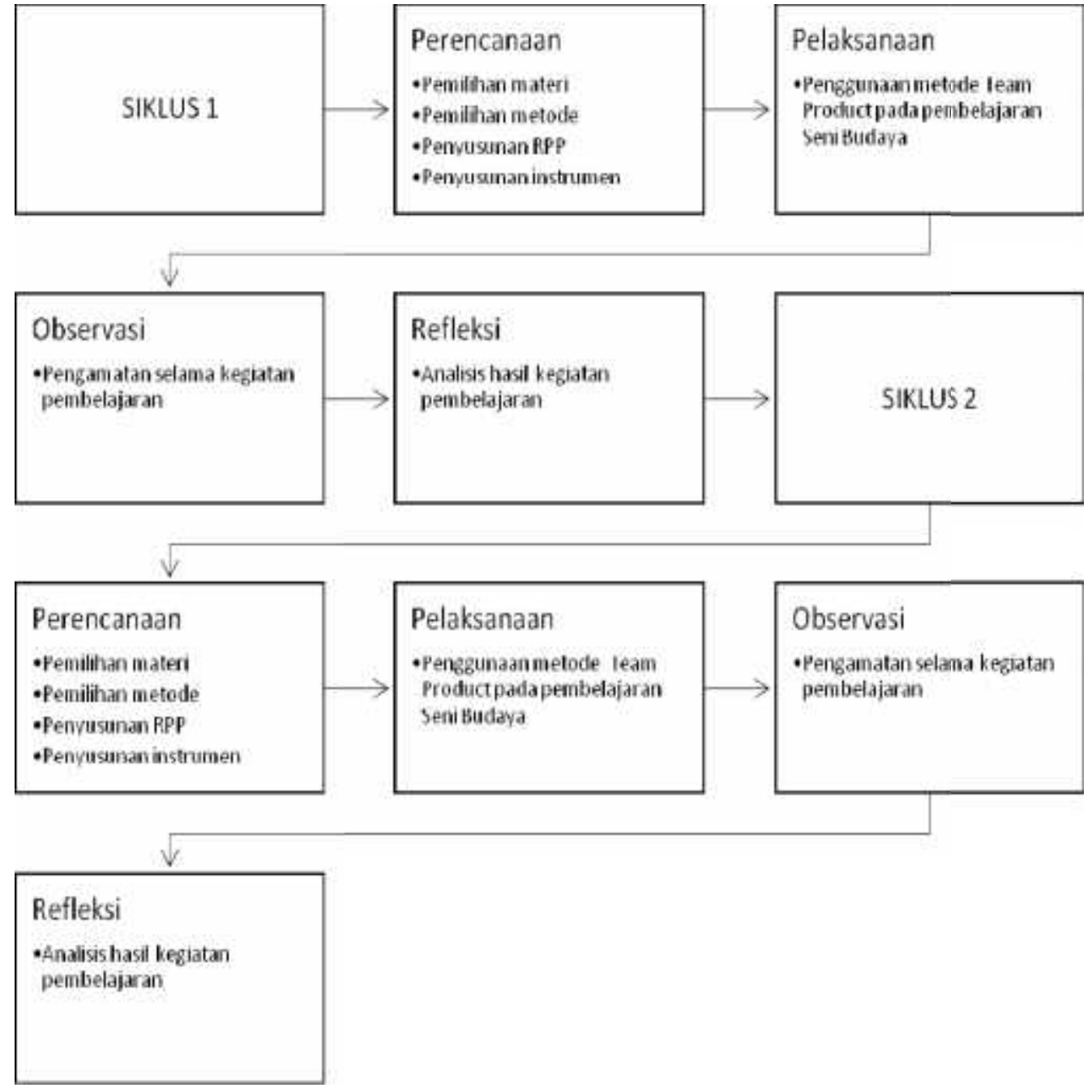

\section{HASIL DAN PEMBAHASAN}

Pada siklus 2 terjadi peningkatan Prestasi Belajar siswa yaitu adanya kenaikan pada nilai tertinggi dan pada rata-rata kelas dibandingkan dengan kondisi awal. Lebih lengkapnya dapat Gambar 1. Diagram Pelaksanaan Tindakan dalam 2

Tabel 1. Tabel Perbandingan Nilai Evaluasi Kondisi awal, Siklus I dan siklus 2

\begin{tabular}{|l|l|c|c|c|}
\hline No & \multicolumn{1}{|c|}{ Uraian } & Kondisi Awal & Siklus 1 & Siklus 2 \\
\hline 1 & Jumlah & 2073 & 2559,3 & 2694 \\
2 & Rerata & 64,78 & 79,98 & 84,19 \\
3 & Nilai Tertinggi & 51 & 74 & 78 \\
4 & Nilai Terendah & 82 & 89,3 & 94 \\
5 & Tuntas & 7 & 25 & 32 \\
6 & Belum Tuntas & 25 & 7 & 0 \\
\hline
\end{tabular}


Data nilai Evaluasi pada kondisi awal dan data nilai siklus I dianalisis dengan menggunakan tekhnik deskriptif komparatif. Rata-rata kelas pada kondisi awal hanya mencapai 64,78 setelah dilakukan tindakan dengan menggunakan metode Team Product pada siklus I nilai rata-rata naik menjadi 79,98 atau terjadi peningkatan $23,5 \%$. Sedangkan pada siklus 2 nilai rata-rata kelas naik lagi menjadi 84,19 atau naik 5,3\% dari siklus 1 dan $30 \%$ dari kondisi awal. Nilai tertinggi pada kondisi awal 82 dan setelah peneliti melakukan tindakan dengan menggunakan metode Team Product terjadi peningkatan nilai tertinggi pada siklus 1 menjadi 89 atau meningkat 6,1\%. Sedangkan pada siklus 2 nilai tertinggi kelas naik lagi menjadi 94 atau naik 13,44\% dari siklus 1 dan 20,73\% dari kondisi awal. Nilai terendah pada kondisi awal 51 sedangkan pada siklus I nilainya terendah 74 atau naik $46 \%$ dari kondisi awal. Sedangkan pada siklus 2 nilai terendah kelas naik lagi menjadi 78 atau naik 7\% dari siklus 1 dan 30\% dari kondisi awal. Interval nilai terendah dengan nilai tertinggi terjadi penurunan, interval nilai pada kondisi awal 31 sedangkan interval nilai pada siklus I 15 terjadi penurunan 16 digit dan pada siklus 2 intervalnya tetap 16 . Ketuntasan belajar siswa naik pesat, pada kondisi awal siswa yang tuntas hanya 7 anak atau $21.87 \%$, pada siklus 1 siswa yang tuntas belajar mencapai 25 atau 78,13\%. Sedangkan pada siklus 2 siswa yang tuntas belajar naik lagi menjadi 32 atau naik $22 \%$ dari siklus 1 dan $78 \%$ dari kondisi awal. Siswa yang belum tuntas belajar mengalami penurunan, yaitu pada kondisi awal ada 25 siswa atau 78,13\% yang belum tuntas, sedangkan pada siklus 1 ada 7 siswa atau $21,8 \%$. Sedangkan pada siklus 2 sudah tidak ada siswa yang belum tuntas belajar. Dari data-data yang telah di tampilkan di atas dapat disimpulkan bahwa terjadi peningkatan ketrampilan dan Prestasi Belajar dalam menampilkan sikap apresiatif terhadap keunikan gagasan dan teknik karya seni rupa terapan nusantara setelah dilakukan tindakan dengan menggunakan metode Team Product.

\section{KESIMPULAN}

Berdasarkan data-data dari kondisi awal sampai dengan siklus 2, maka dapat diambil kesimpulan berdasarkan teoritik hipotesis menyebutkan melalui metode Team Product dapat meningkatkan ketrampilan siswa VIII D SMP Negeri 1 Nusawungu Semester I Tahun Pelajaran 2015/2016 dalam pembelajaran Seni Budaya dengan materi menampilkan sikap apresiatif terhadap keunikan gagasan dan teknik karya seni rupa terapan nusantara dari kondisi awal yang rendah ke kondisi akhir yang tinggi. Maka baik secara teoritik maupun empirik melalui metode Team Product dapat meningkatkan $\underline{\text { ketrampilan siswa kelas VIII D SMP Negeri } 1 \text { Nusawungu Semester I Tahun Pelajaran }}$ 
2015/2016 dalam pembelajaran Seni Budaya dengan materi menampilkan sikap apresiatif terhadap keunikan gagasan dan teknik karya seni rupa terapan nusantara dari kondisi awal yang rendah ke kondisi akhir yang tinggi. Berdasarkan teoritik hipotesis dan empirik menyebutkan melalui penggunaan metode Team Product dapat meningkatkan hasil belajar siswa kelas VIII D SMP Negeri 1 Nusawungu Semester I Tahun Pelajaran 2015/2016 dalam pembelajaran Seni Budaya dengan materi menampilkan sikap apresiatif terhadap keunikan gagasan dan teknik karya seni rupa terapan nusantara dari kondisi awal yang rata-ratanya hanya 64,78 meningkat menjadi 84,19 pada kondisi akhir. Maka baik secara teoritik maupun empirik melalui penggunaan metode Team Product dapat meningkatkan hasil belajar siswa kelas VIII D SMP Negeri 1 Nusawungu Semester I Tahun Pelajaran 2015/2016 dalam pembelajaran Seni Budaya dengan materi menampilkan sikap apresiatif terhadap keunikan gagasan dan teknik karya seni rupa terapan nusantara dari kondisi awal yang rendah ke kondisi akhir yang tinggi. Berdasarkan teoritik dan empirik penggunaan metode Team Product dapat meningkatkan ketrampilan dan hasil belajar siswa kelas VIII D SMP Negeri 1 Nusawungu Semester I Tahun Pelajaran 2015/2016 dalam pembelajaran Seni Budaya dengan materi menampilkan sikap apresiatif terhadap keunikan gagasan dan teknik karya seni rupa terapan nusantara.

\section{SARAN}

Pada penelitian berikutnya perlu diperdalam penelitian tentang mata pelajaran seni rupa dengan menerapkan berbagai metode pembelajaran

\section{DAFTAR PUSTAKA}

Agus Suprijono, 2012, Cooperative Learning Teori dan Aplikasi Paikem, Yogyakarta.

Depdiknas, 2003, Kurikulum 2004 Standar Kompetensi, Jakarta : Depdiknas

Djudi, 1988, Didaktik Metodik, Semarang : Fakultas Tarbiyah IAIN Walisongo. Google, 2015. Pengertian Kebudayaan. www.artikelsiana.com

Masyhuri HP, 1990, Azas-azas Belajar, Semarang : IKIP Semarang Press

Nana Sudjana, 2012. Penilaian Proses Belajar dan Mengajar, Bandung Rosdakarya.

Prayitno, 2007. Permasalahan dan Kajian Teori dalam Penelitian Tindakan Kelas, Kebumen, Dinas Pendidikan Kabupaten Kebumen

Tim Pengembangan MKDK IKIP Semarang, 1990, Psikologi Belajar, Semarang : IKIP Semarang Press. 
AoEJ : Academy of Education Journal

Vol.09 No 1 Tahun 2018

Udin S Winataputra, 2007. Belajar dan Pembelajaran, Jakarta : Depdiknas.

Utami Munandar, 2002. Mengembangkan Bakat dan Kreativitas Anak Sekolah. 